\title{
The Evaluation of Teaching Level and Exploration of Improving Ability for Young Teachers in Higher Education
}

\author{
—The First Teaching Competition for Young College Teachers in Jiangxi \\ Province in 2014 as an Example
}

\author{
Zhang Liu*, Fang Mei, Juhua Hu, Jiangen Hu \\ College of Sciences, Jiangxi Agricultural University, Nanchang, China \\ Email: *liuzhang1006@163.com
}

Received 25 September 2014; accepted 17 May 2015; published 19 June 2015

Copyright (C) 2015 by authors and Scientific Research Publishing Inc.

This work is licensed under the Creative Commons Attribution International License (CC BY).

http://creativecommons.org/licenses/by/4.0/

(c) (i) Open Access

\begin{abstract}
By analyzing the final results sample of teaching competition of the first young college teachers in Jiangxi Province in 2014, we give a comprehensive evaluation for the subject composition and the title of young teachers in higher education, which can provide a reference and basis for the university managers to adopt more scientific teaching methods and means to improve the quality of higher education. Meanwhile, for the lack of teaching experiences' young teachers, we bring out effective ways to improve the teaching level from curriculum, instructional design, classroom teaching and teaching reflection.
\end{abstract}

Keywords

Comprehensive Evaluation, Teaching Level, Teaching Competition, Young Teachers

\section{Introduction}

Young teachers are an important part in college teaching work, their teaching quality is one of the important indexes to reflect the level of colleges and universities. With the rapid development of higher education and the continuous expansion of the scale of higher education in China, there are a large number of outstanding graduates to join in the college teaching team. Relevant statistics show that the young teachers under the age of 40 account for more than $50 \%$ of the total number of full-time teachers in Chinese current universities, in some new universities the percent is more (Zhang \& Li, 2013). Therefore, the teaching abilities and levels of young teach-

\footnotetext{
*Corresponding author.
}

How to cite this paper: Liu, Z., Mei, F., Hu, J. H., \& Hu, J. G. (2015). The Evaluation of Teaching Level and Exploration of Improving Ability for Young Teachers in Higher Education-The First Teaching Competition for Young College Teachers in Jiangxi Province in 2014 as an Example. Creative Education, 6, 976-981. http://dx.doi.org/10.4236/ce.2015.610099 
ers directly determine the qualities and levels of the higher education. Each university should make great efforts and take various measures to effectively improve the teaching level of young teachers. More references can be seen in: Berk (2005), Chen (2011), Hoon et al. (2014), Armstrong (2012), Langbein (2008) and Leong (2012).

The comprehensive evaluation and reasonable plan on the teaching quality of young teachers are important means to raise the teaching level in colleges and universities. It is necessary to evaluate the teaching level of young teachers from various aspects in order to promote the young teachers in colleges and universities as well as the overall improvement of teaching level. More results on this topic can be found in the following references: Marks (2012), Merritt (2008), McPherson et al. (2009), Rahman (2006), Spooren et al. (2007), Weinberg et al. (2009) and Zhang (2011). In this paper, by the sample of the final results of the first young college teachers' teaching competition in Jiangxi Province in 2014, we give a comprehensive teaching quality evaluation for the composition of participating subjects, titles, and the final results. We also analyze the reasons for some of the differences, which can provide a reference and basis to help the university managers to adopt more scientific teaching methods and means to improve the quality of higher education.

\section{Competition Process and Performance Analysis}

\subsection{Form and Implementation of the Competition}

The first teaching competition of young teachers for colleges and universities in Jiangxi province began to organize in 2014, from late April to early July. According to different subjects the competition was divided into three groups: the humanities and social sciences, the foundation of natural science and the application of natural science. The competition period was divided into three stages: (1) Preliminaries. By carrying out teaching competition activities in various forms, each college or university selected the first teacher of three groups to participate the semi-finals organized by the Provincial Education Department; (2) Semi-finals. The semi-finals chose the winners by the form of teaching video discs of young teachers. The teaching videos were scored and selected by the teaching evaluation committee; (3) Finals. 67 young teachers were selected from the semi-finals in three teaching groups to participate in the finals in Jiangxi province.

\subsection{Content and Process of the Competition}

The competition uses "teaching a good class" as the concept. The participant young teachers are required to provide a course syllabus and the competition contents consist of teaching design, classroom teaching and teaching reflection. The process of competition is as follows: (1) Before the finals, each participant teachers need complete 20 teaching designs and the corresponding 20 PPT for their course; (2) Before the competitive day, each teacher draws lots to determine the participant order and the specific segments of classroom teaching; (3) At the end of the classroom teaching, teaching reflection needs to be written in the specified classroom.

\subsection{Scoring System of the Competition}

The evaluation of teaching level for young teachers is a relative process, which can be discussed from multiple angles. In order to make the results of the evaluation be objective and impartial, this competition sets up a special "teaching competition committee" by members of the well-known experts and professors in colleges and universities. Three indicators: teaching design (accounting for 15\%), classroom teaching (accounting for 80\%) and teaching reflection (accounting for $5 \%$ ) are scored by the teaching competition committee. Each group consists of 8 judges, by eliminating the highest and lowest scores, the average value of the remaining 6 scores is the final score of the participating teachers. Specific evaluation details are as follows in Table 1.

\subsection{Results Evaluation of the Competition}

(1) The composition of final personnel

In the 67 young teachers of the finals, the lecturers have a total of 51 people and account for $76.1 \%$. The professors, associate professors and assistants account for respectively 3.0\%, 17.9\% and 3.0\% (Table 2). By analyzing the constitutions of the title of the young teachers, we can see that the proportion of lecturer title accounts for the majority, which indicates that young teachers who have lecturer title of the competition show very high enthusiasm. In addition, the competition requires contestants' age under 40 years old, so the teachers who have professor title participate rarely. Due to the work time of young teachers who have assistant title is short, so this 
Table 1. The standard scores of the teaching competition (including: teaching design, classroom teaching, teaching reflection).

\begin{tabular}{|c|c|c|}
\hline Project & Evaluation requirement & Score \\
\hline \multirow{6}{*}{$\begin{array}{c}\text { Teaching } \\
\text { design } \\
\left(15^{\prime}\right)\end{array}$} & Consistent with the syllabus, informative, reflecting the frontier of the subject & 2 \\
\hline & Targeted teaching, clear thinking & 2 \\
\hline & Accurately grasp the key points and difficult points of the courses & 5 \\
\hline & Use the appropriate and effective methods and means, rationally organize the teaching process & 4 \\
\hline & The expression is accurate, concise, clearly explained & 2 \\
\hline & Theory with practice, in line with the characteristics of students & 8 \\
\hline \multirow{12}{*}{$\begin{array}{c}\text { Classroom } \\
\text { teaching } \\
\left(80^{\prime}\right)\end{array}$} & $\begin{array}{l}\text { Focus on academic, informative, professional } \\
\text { and ideological penetration, service for teaching target }\end{array}$ & 10 \\
\hline & Contact the discipline, reflect the development of new ideas, new concepts, new results & 3 \\
\hline & Focused, well organized, step by step & 11 \\
\hline & $\begin{array}{l}\text { Reasonable arrangements for the teaching process, } \\
\text { using flexible methods, appropriate teaching design }\end{array}$ & 11 \\
\hline & Inspiring strong, effectively mobilize the enthusiasm of the students' thinking and learning & 11 \\
\hline & Teaching schedule is reasonable & 3 \\
\hline & Skilled and effective use of modern teaching methods such as multimedia & 4 \\
\hline & $\begin{array}{l}\text { Blackboard design is close to teaching content. Writing on the blackboard should } \\
\text { be compatible to multimedia. simple, neat, beautiful, appropriate size }\end{array}$ & 3 \\
\hline & The language clear, smooth, accurate and vivid; The speed of rhythm is proper & 5 \\
\hline & Body language should be reasonable and appropriate, teaching state is natural & 4 \\
\hline & Natural teaching state, full of energy, strong affinity & 2 \\
\hline & Advanced teaching philosophy, style prominent, strong infection, effective teaching & 5 \\
\hline $\begin{array}{l}\text { teaching reflec- } \\
\text { tion (5') }\end{array}$ & $\begin{array}{l}\text { From teaching philosophy, teaching methods, teaching process three aspects, } \\
\text { theory with practice, view clear, arts and fluent, feeling expression. }\end{array}$ & 5 \\
\hline
\end{tabular}

Table 2. The title composition of young teachers in each category.

\begin{tabular}{ccccc}
\hline Title & $\begin{array}{c}\text { Humanities and } \\
\text { social sciences }\end{array}$ & $\begin{array}{c}\text { The foundation } \\
\text { of natural science }\end{array}$ & $\begin{array}{c}\text { The application } \\
\text { of natural science }\end{array}$ & $\begin{array}{c}\text { Total number } \\
\text { (percentage) }\end{array}$ \\
\hline Professor & 0 & 1 & 1 & 7 \\
Associate professor & 2 & 3 & $12(17.9 \%)$ \\
Lecturer & 18 & 18 & 15 & 0 \\
Teaching assistant & 2 & 0 & 0 & $2(3 \%)$ \\
\hline
\end{tabular}

kind of participants is very small.

(2) Result analysis of subject groups

In the finals, the highest score is 92.48 , the lowest score is 70.32 and the average score is 84.67 . We divide all the competition achievements of participant teachers into three groups: first-class group (top three in each category), second-class group (each group 4 - 10), third-class group (each group after 11). In the first-class group, the proportion of associate professor accounts for $22.2 \%$ and the lecturer $77.8 \%$. Comparison with other entries, we find that associate professors and lecturers do well in showing their teaching ability. Especially when we investigate the front 5 ranking in three groups, we find that the associate professors account for $13.3 \%$ and lecturers account for $86.7 \%$. In all first-class and second-class groups, none of whom has the title of assistant teacher, which shows young teachers who have assistant titles are still lacking teaching experience and their teaching 
level is generally not high, there are a lot of teaching skills for them to learn.

By the composite evaluation for the three groups: the humanities and social sciences, the foundation of natural science and the application of natural science, we find that the results are quite different, which are shown in Table 3.

From Table 3, considering the highest score, the lowest score, and the average score, we find that the scores of the application of natural science group are significantly higher and the scores of the humanities and social sciences group are not very high. But the value of standard deviation of the humanities and social sciences group is large, which shows the greater volatility of teaching ability in the group of young teachers. Through this contest, some outstanding and high teaching level young teachers were discovered and they showed their good teaching ability in the competition. Not only that, in the end of the race meeting, almost all the young teachers said the race greatly promoted and improved their teaching level, many teachers said they hoped to participate in this kind of race to display their teaching ability, which indicated that the competition well done the main objective of "teaching a good class".

\section{The Way to Improve the Teaching Ability of Young Teachers}

College teachers play significant roles in training researchable and innovative talents. Young teachers are the reserve army for the forward development of the university. In particular, they should play their roles well. They must learn to summarize their teaching experience and constantly improve their teaching level. They should not simply consider the university teaching as talking in the class, obsessing the book and solving the problem. To paraphrase a word of the professor Pingyuan Chen, Chinese Dean of Peking University, "the discussion related to curriculum design, classroom teaching before or after school, and so on, do not think it is insignificant skill, in fact, a great relationship” (Chen, 2011). Young teachers should adhere to improve the teaching ideas, master the modern teaching methods, summarize the experience and practice, to further improve their teaching ability and the professional level. Combining the four aspects of the teaching competition "teaching curriculum, teaching design, classroom teaching, teaching reflection”, we now talk about how to improve the comprehensive teaching ability of young teachers.

Start with the syllabus. "Syllabus" is a programmatic guiding document and is a combination of teaching content, teaching requirements and the general overview of difficulties for a course. If the young college teachers want to have a good course teaching, firstly they have the requirements of specific, systematic and scientific grasp of the course syllabus. Through the teaching syllabus of the course, they may have a clear understanding of definition, curriculum of scope, depth and structure, which have a positive role in guiding the young teachers in the process of teaching a course.

Discuss on teaching design. According to the teaching objectives, reasonable arrangement of the classroom teaching process, young teachers need clearly explain the problem of "what to teach" and "how to teach". In this competition, the scores of teaching design account for $15 \%$, it means that teaching design is very important for "teaching a good class". Before the classroom teaching, it is necessary to give a reasonable design for teaching content, which includes teaching purpose, basic aspects, curriculum structure, logical order, and media use (such as graphics, model, PPT, etc.); not only that, in the process of design, young teachers need pay special attention to a series of teaching ideas such that the organization of teaching process is reasonable and the teaching methods are appropriately and effectively used.

Now talk about classroom teaching. A "profound knowledge" teacher must also use the appropriate communication and expression to impart their knowledge, and classroom teaching is the main way to teach their own knowledge. The effect of classroom teaching directly determines the degree of grasping knowledge of students, which is closely related to a course of teaching philosophy, teachers preparing lessons, teaching skills and strategies. Young teachers can follow five aspects "doubt, thinking, discovery, FAQ, summary" so as to teach a course well. Through the first two links, the origins of the problems and methods of solving problems can be

Table 3. The performance analysis for three groups.

\begin{tabular}{|c|c|c|c|c|}
\hline Group & Highest score & Lowest score & Average score & Standard deviation \\
\hline humanities and social sciences & 91.26 & 70.32 & 83.26 & 5.22 \\
\hline the foundation of natural science & 90.79 & 77.99 & 84.59 & 3.73 \\
\hline the application of natural science & 92.48 & 78.52 & 86.08 & 3.44 \\
\hline
\end{tabular}


clearly expounded. Through the last two steps, good extension thinking can enable students to deepen the understanding of the content. The five aspects is consistent with five step teaching methods "ask a question, analyze the problem, solve problems, example application, analyze and summary" (Yao, 2014), said by the National Teaching Professor Duanzheng Yao.

Finally talk about teaching reflection. Teaching reflection is a process of rethinking, recognition and reevaluation for teaching practice, and then gradually improving the teaching level based on the process. Teaching reflection takes an essential part in teaching process (Zhang, 2011). From the finals, we found the player scores of teaching reflection were relatively low, some even fail, which reflected that the young teachers didn't pay enough attention to teaching reflection and they didn't know why to write and how to write the teaching reflection. In fact, when finished a lesson, it is very important to record the most wonderful place, to summarize no smooth place, and to expand thinking and re-understanding of the class in the teaching activities. Through continuous accumulation of teaching reflection, young teachers can gradually improve their own teaching methods. As the famous educator Lan Ye said, "A teacher do not necessarily become a famous teacher by writing lesson plans in a whole life, if a teacher write teaching reflection for three years, he might be a famous teacher" (Ye, 2013), we can see the importance of teaching reflection for the growth of a young teacher.

Teaching is a kind of practice, through the constant practice the teaching level of young teachers can be effectively improved. But lack of theoretical guidance and experience summary, only practice is not enough. In the process of the teaching practice and teaching summary, young teachers also need pay attention to the mutual exchanges, focus on learning good teaching methods from experts, step by step, and gradually improve their teaching ability.

\section{Support}

This paper is supported by the reform project of Jiangxi Province (No. JXJG-10-4-22) and the school project of Jiangxi Agricultural University (No. 09003326).

\section{References}

Berk, R. A. (2005) Survey of 12 Strategies to Measure Teaching Effectiveness. International Journal of Teaching and Learning in Higher Education, 17, 48-62.

Chen, P. Y. (2011). What to Teach, How to Teach? China University Teaching, 2, 4-6.

Hoon, A. E., Oliver, E., Szpakowska, K., \& Newton, P. M. (2014). Use of the “Stop, Start, Continue” Method Is Associated with the Production of Constructive Qualitative Feedback by Students in Higher Education. Assessment and Evaluation in Higher Education. http://dx.doi.org/10.1080/02602938.2014.956282

Armstrong, J. S. (2012). Natural Learning in Higher Education. In N. M. Seel (Ed.), Encyclopedia of the Sciences of Learning (pp. 2426-2433). New York: Springer.

Langbein, L. (2008). Management by Results: Student Evaluation of Faculty Teaching and the Mis-Measurement of Performance. Economics of Education Review, 27, 417-428. http://dx.doi.org/10.1016/j.econedurev.2006.12.003

Leong, C. K., Lee, Y. H., \& Mak, W. K. (2012). Mining Sentiments in SMS Texts for Teaching Evaluation. Expert Systems with Applications, 39, 2584-2589. http://dx.doi.org/10.1016/j.eswa.2011.08.113

Marks, P. (2012). Silent Partners: Student Course Evaluations and the Construction of Pedagogical Worlds. Canadian Journal for Studies in Discourse and Writing, 24, 1-32.

Merritt, D. (2008). Bias, the Brain, and Student Evaluations of Teaching. St. John's Law Review, 82, 235-287.

McPherson, M. A., Jewell, R. T., \& Kim, M. (2009). What Determines Student Evaluation Scores? A Random Effects Analysis of Undergraduate Economics Classes. Eastern Economic Journal, 35, 37-51. http://dx.doi.org/10.1057/palgrave.eej.9050042

Rahman, K. (2006). Learning from Your Business Lectures: Using Stepwise Regression to Understand Course Evaluation Data. Journal of American Academy of Business, Cambridge, 19, 272-279.

Spooren, P., Mortelmans, D., \& Denekens, J. (2007). Student Evaluation of Teaching Quality in Higher Education: Development of an Instrument Based on 10 Likert-Scales. Assessment \& Evaluation in Higher Education, 32, 667-679. http://dx.doi.org/10.1080/02602930601117191

Weinberg, B. A., Hashimoto, M., \& Fleisher, B. M. (2009). Evaluating Teaching in Higher Education. Journal of Economic Education, 40, 227-261. http://dx.doi.org/10.3200/JECE.40.3.227-261 
Yao, D. Z. (2014). Learn as Teachers, Behavior Norms, to Be Qualified University Teachers in New Century. Discussion on Teaching and Literacy, 2, 111-122.

Ye, L. (2013). School of Life • Practice Pedagogy: Creation in Return and Breakthrough. Journal of Educational Studies, 10, 3-23.

Zhang, C. W. (2011). Study on the Problems and Countermeasures of Teaching Reflection for Young College Teachers. Proceedings of the International Conference on Education Science and Management Engineering, Beijing, 16-18 August 2011, 1961-1964.

Zhang, S. X. (2011). Evaluation of Curriculum Teaching Effect or Appraisal of Teacher's Teaching Level—Thoughts on Reform and Improvement of Teaching Quality Evaluation in Universities and Colleges. Modem Educational Technology, 3, 61-63.

Zhang, Z. H., \& Li, T. T. (2013). A Discussion on University Yong Teachers’ Instructional Ability Structure and Strategy for Development: An Analysis Based on the Conclusions and Logic of Investigative Research. China Higher Education Research, 4, 51-55. 